[DOI: 10.24214/jecet.A.10.3.31622.]

Jaurnal of Environmental Science, Computer Science and Engineering \& Technology

An International Peer Review E-3 Journal of Sciences and Technology

Available online at www.jecet.org

Section A: Environmental Science

Research Article

\title{
Current situation of recycling aluminum in Albania
}

\author{
Eneida Mara ${ }^{1}$ and Spiro Drushku ${ }^{2}$ \\ ${ }^{1}$ Chemical Sub-chapter Coordinator, SANE 27-Support Albanian Negotiation in \\ Environment Chapter 27, Tirana, Albania, \\ ${ }^{2}$ Dean of Faculty of Natural Sciences, Tirana University, Albania.
}

Received: 14 June 2021; Revised: 21 June 2021; Accepted: 30 June 2021

\begin{abstract}
From the environmental aspect, aluminum recycling has many advantages starting from collecting, separation and melting of scraps. Aluminum is totally recyclable, which makes this an increasingly lucrative process. In addition, aluminum scrap recycling is a key element in the aluminum industry and in a sustainable future, due to a combination of its characteristics, such as weight, strength, stability and recyclability. All products containing aluminum are potential scrap sources. The process of secondary aluminum production from scrap recycling includes: collecting and separating scraps, pretreatment, melting and refinement. The scrap collection lines are considered one of the factors that influence the secondary aluminum prices. Aluminum scraps are categorized into old and new scraps, such that new scraps are ca. $100 \%$ recyclable before direct consumption even in the melting-recycling line. Therefore, old scraps are the key point in the collection and recycling processes. The lifecycle and availability for recycling vary due to the nature of the product and its application.
\end{abstract}

Keywords: secondary aluminum, scrap, recycle, aluminum, energy

\section{INTRODUCTION}

Since 2014 Albania is a potential country for the EU membership and for this reason is developing and implementing policies e.g. DCM No 177 "For package and their waste," law for the Integrated Management of Waste, which transpose the Directive 2008/98/EC of the European Parliament, on waste, set the objectives and rules of recycling and recovery of waste from packaging. In general recycling plays an important role in Albania. Both formal and informal sectors are involved in the 
recycling activities that take place in Albania. Most of the people who collect recyclable materials belong to the informal sector,

Table 1: Weight of waste streams in Albania - 2019

\begin{tabular}{|c|c|c|c|}
\hline Waste Stream & $\begin{array}{c}\text { National Average } \\
{[\mathbf{\%}]}\end{array}$ & Waste Stream & $\begin{array}{c}\text { National Average } \\
{[\%]}\end{array}$ \\
\hline Organics & 47.3 & Metals (colorless) & 0.57 \\
\hline Wood & 1.43 & Hospital waste & 0.17 \\
\hline Paper & 5.37 & Tires & 0.2 \\
\hline Cardboard & 8.13 & Inert & 7.2 \\
\hline Plastic LDPE & 8.46 & Other & 3.25 \\
\hline Plastic HDPE & 4.75 & WEEE & 0.31 \\
\hline Glass & 5.75 & Battery & 0.02 \\
\hline Textile & 5.27 & Animal by-products & 1.08 \\
\hline Metals (non- & 0.56 & & \\
\hline
\end{tabular}

Sustainable development means meeting certain conditions: maintaining an overall balance, respect for the environment and preventing the destruction of natural resources. Reducing waste production and streamlining energy production and consumption must be implemented. The aluminum recycling industry in Albania is relatively new (after 2011), and it's undergoing a series of challenges to form as efficient a recycling economy as possible.

\section{MATERIALS AND METHODS}

There is little information on scrap generation and collection at country level, even at regional level in the Western Balkan Countries. In Albania exist and operate conform environmental rules 5 facilities unit for the recycling aluminum. As a result of the study it was noticed that most of the lines that recycle aluminum are built in rural areas and in the vicinity of agricultural lands. Also for logistical reasons those are located near the main national port. The major trade destinations for Albania's aluminum scrap importation are Belgium, Bulgaria, Croatia, Cyprus, Denmark, Greece, Italy, Netherlands, etc. Scrap collection and recycling in developed countries has improved progressively in the past 20 years and is well integrated in the metal industry. The global recycling efficiency rate is $76 \%$.

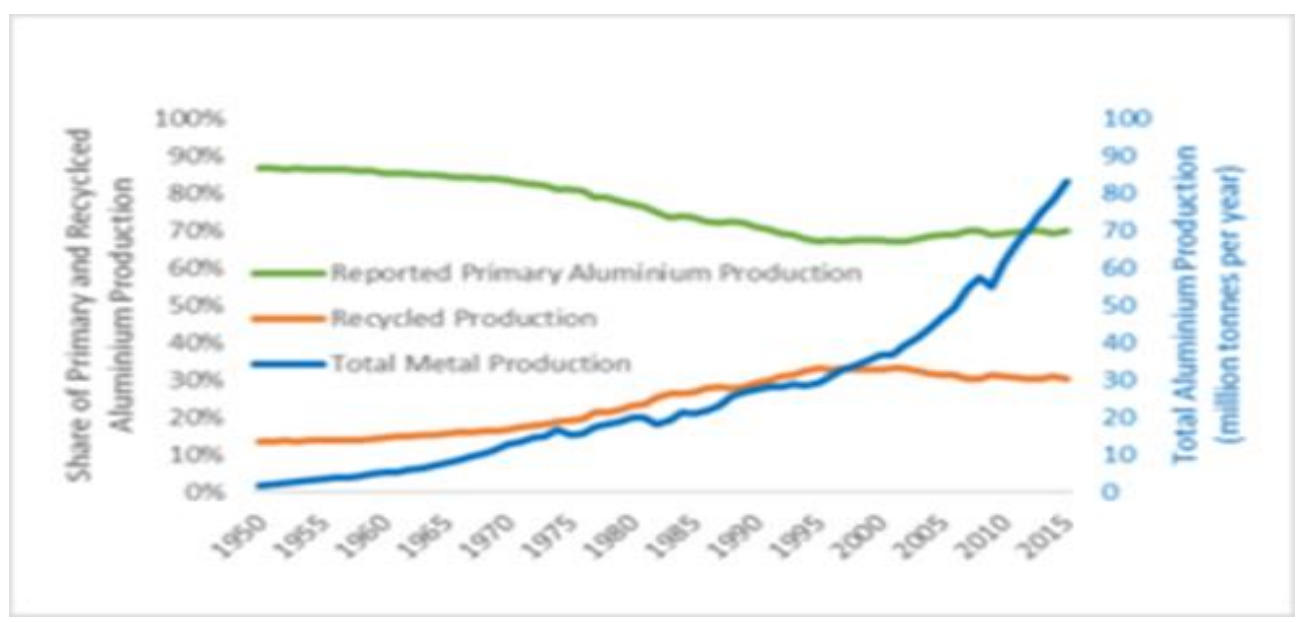

Figure 1: Primary and recycle metal production (recycling.world-aluminium.org) 
High recycling rates in all regions underline the economic and environmental value of aluminum scrap (source IAI). Every year, more than 30 million tons of aluminum scrap is recycled globally, ensuring its status as one of the most recycled materials on the planet. (International-aluminiuminstitute-publishes-global-recycling-data - 2020). Europe has the highest Recycling Efficiency Rate (RER) in the world, recovering $81 \%$ of aluminum scrap available in the region.

In 2003 the European standard EN 13920 was approved, on aluminum and aluminum scrap, which includes all types of scrap. The materials used generally in the recycling facilities in Albania are materials collecting according to the Law No 99 "For the approval of the Albanian Catalogue of Waste Classification".

Recycling of aluminum has great advantages over primary aluminum production due to its lower cost and less energy consumption (9). Its processes and products by promoting an efficient use of resources and energy, reduction of emissions to air and water, reduction of waste, high recycling rates at the end of the product life-cycle.

Secondary aluminum is produced from recycled scrap that is either generated at the smelter and fabrication plants or collected post consumption. Thus the aluminum scrap is categorized as: new and old, due the distinction of pre or post consumption. New scrap is generated and recycled within the same facility. The composition of that scrap is known by the re-melters, is clean and don't need treatment before re-melting.

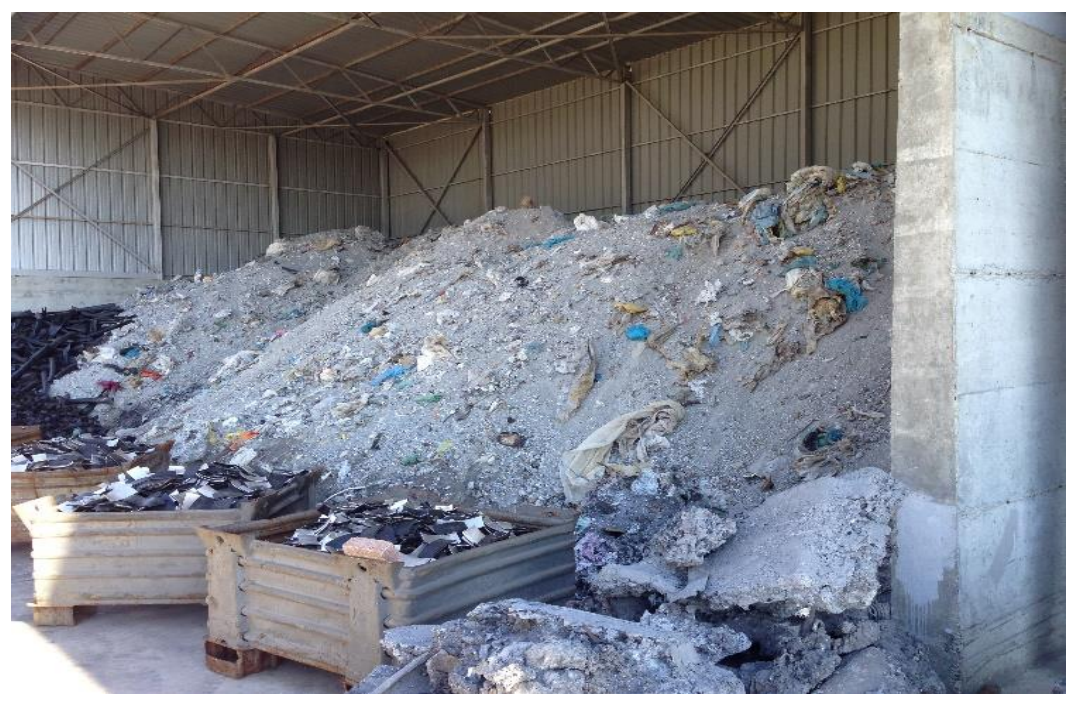

Figure 2: Scrap - 30\%

The transportation sector and packaging aluminum have been, and still are the main sources of old scrap. Aluminum packaging waste is a large short term source of scrap. Most of the products used in food packaging have less than a one year life time. The current consumption at world level is close to $5 \mathrm{Mt}$ per year. The sector contributes to nearly $28 \%$ of the recycled aluminum, second after the transportation sector. The overall rate of recycling of aluminum in the sector is around $36 \%$, mainly from beverage cans (Source: EAA, 2006). Profiles, cans, plates etc. in wrought aluminum are normally low in alloy components and can be used in almost all secondary processes. In the mechanical recovery of wrought aluminum, the main task is sorting the scrap to separate of heavy metal components, which are exposed during shredding, e.g. by hammer mill or rotary shear. Cleaning the scrap to remove dirt and other extraneous material, briquetting the scrap to make subsequent transport easier, simple melting to separate aluminum in the scrap from attached iron and converting the scrap to ingot. 


\section{RESULTS AND DISCUSSION}

During secondary aluminum recovery, aluminum scraps are melted and refined often in a rotary melting furnace under a molten salt layer, Efficient melting of the scrap is a critical issue in order to achieve higher metal recovery, lower energy and salt consumption, and less environmental impact. Reverberatory furnaces can emit a variety of interesting substances when melting aluminum scrap. The most significant of these are chloride gases and vapors. Scrap that has not been decoated often contains chlorinated polymer coatings, such as PVC. Along with this, scrap charging often generates dust that must be dealt with. The standard reverberatory furnace is the most common technology in secondary aluminum production and generally employed to treat large volumes of smaller size scrap.

Out of total semi-fabricated and cast products demand, around a quarter is for transport and construction industries each (26\% and $25 \%$ respectively), while demand for foil \& packaging and electrical segment are around 15\% each, and machinery \& equipment 10\% (consumer durables and other are 10\%, 5\% each (aluminiuminsider.com/explaining-global-aluminium-flows-and-smeltercosts/). Referring to the firms and measured losses in line, the table below provides some key indicators in relation to the raw material for several processing cycles derived from production reports.

Table 2. Quantity of raw material for the ingots production

\begin{tabular}{|l|l|l|l|l|l|l|l|l|}
\hline $\begin{array}{l}\text { No } \\
\text { Cycle }\end{array}$ & $\begin{array}{l}\text { Enter in } \\
\text { produce } \\
\text { Scrap + } \\
\text { Silica/ } \\
\text { Kg }\end{array}$ & $\begin{array}{l}\text { Ingot } \\
\text { KKg }\end{array}$ & $\begin{array}{l}\text { Coefficient } \\
\text { compensation } \\
\text { main product }\end{array}$ & $\begin{array}{l}\text { Total } \\
\text { furnaces }\end{array}$ & $\begin{array}{l}\text { Total } \mathbf{O}_{2} \\
/ \text { Kg }\end{array}$ & $\begin{array}{l}\text { Total } \\
\text { LPG/Kg }\end{array}$ & Salt/kg & $\begin{array}{l}\text { Silica/ } \\
\text { kg }\end{array}$ \\
\hline 1 & 2 & 3 & $4=3 / 2 \times 100$ & 5 & 6 & 7 & 8 & 9 \\
\hline Cycle 001 & 35,928 & 28,781 & 80.11 & 3 & 5,245 & 5,940 & & 2020 \\
\hline Cycle 002 & 63,440 & 26,800 & 42.24 & 5 & 11,200 & 4,888 & 25500 & \\
\hline Cycle 003 & 51,438 & 25,826 & 50.21 & 4 & 10,220 & 4,100 & 21900 & \\
\hline Cycle 004 & 139,231 & 66,849 & 48.01 & 12 & 39,690 & 20,172 & 61591 & 830 \\
\hline Cycle 005 & 50,127 & 20,687 & 41.27 & 4 & 20,307 & 7,750 & 22557 & 900 \\
\hline Cycle 006 & 76,700 & 23,670 & 30.86 & 6 & 11,122 & 7,670 & 28854 & \\
\hline Cycle 007 & 6,467 & 5,382 & 83.22 & 1 & 1,500 & 4,838 & 28854 & 480 \\
\hline Cycle 008 & 30,219 & 28,276 & 93.57 & 3 & 9,860 & 6,400 & & 1470 \\
\hline Cycle 009 & 170,265 & 118,324 & 69.49 & 11 & 24,300 & 19,794 & 60500 & 12000 \\
\hline Cycle 010 & 9,400 & 3,880 & 41.28 & 1 & 1,700 & 5,860 & & \\
\hline Cycle 011 & 55,372 & 27,017 & 48.79 & 6 & 9,000 & 5,300 & 39600 & 1400 \\
\hline Cycle 012 & 86,661 & 37,580 & 43.36 & 9 & 13,500 & 10,800 & 44104 & 720 \\
\hline
\end{tabular}

Before entering the smelting furnaces, the aluminum scrap is pre-treated, first through a shredder to eliminate residual water and other contaminants. The uniform mass of the shredder helps the material to flow in further processes. The pieces are passed through a magnetic separator to eliminate iron contamination. In some cases, air knives are also used to prevent the addition of heavy contaminants such as lead, steel or zinc. The scrap is then subjected to de-stratification, where the scrap is heated and as a result evaporation and oxidation of the layers occurs. Depending on the use, the metal is further processed in a filter to remove any potential oxide that may have formed. The heated material by means of pneumatic cylinders is then introduced into the melting furnace. 
Table 3: Air Emission

\begin{tabular}{|c|c|c|c|}
\hline \multicolumn{5}{|c|}{ Air Emissions from Primary and Secondary Aluminum Production } \\
\hline Chemical & $\begin{array}{l}\text { Primary Emission } \\
\text { (kg/mt) }\end{array}$ & $\begin{array}{l}\text { Secondary Emission } \\
\text { (kg/mt) }\end{array}$ & $\begin{array}{l}\text { Percent } \\
\text { Reduction }\end{array}$ \\
\hline $\mathrm{CO}_{2}$ & 15,300 & 702 & 95.4 \\
\hline $\mathrm{CO}$ & 519 & 1.21 & 99.8 \\
\hline $\mathrm{SO}_{2}$ & 53.5 & 1.2 & 97.8 \\
\hline $\mathrm{NO}_{\mathrm{X}}$ & 40.4 & 1.79 & 95.6 \\
\hline $\mathrm{CH}_{4}$ & 34 & 0.614 & 98.2 \\
\hline $\mathrm{CF}_{4}$ & 0.0858 & 0 & 100 \\
\hline $\mathrm{C}_{2} \mathrm{~F}_{6}$ & 0.0104 & 0 & 100 \\
\hline $\mathrm{HF}$ & 8.01 & 0 & 100 \\
\hline $\mathrm{PAH}$ & 0.0266 & 0 & 100 \\
\hline
\end{tabular}

Source: After Ding, N.et al., Procedia Eng., 27, 465, 2012.

The flue gas purification plant is monitored continually and undergoes routine maintenance. The emissions from the smelting furnaces are analyzed regularly to ensure that they comply with the applicable regulations.

Based on the survey on the facilities of ingots production here in Albania, below are the data:

Table 4: Air emission for every production cycle.

\begin{tabular}{|c|c|c|c|c|c|c|}
\hline Air Emissions & & & & & & \\
\hline Air temp. $\left({ }^{\circ} \mathrm{C}\right)$ & 14 & 31 & 15.3 & & & \\
\hline Pressure (atm) & 1.009 & 1.009 & & & & \\
\hline Humidity (\%) & 59 & 36 & 45.3 & & & \\
\hline Wind speed $(\mathbf{k m} / \mathbf{h})$ & 10 & 11 & 1.12 & & & \\
\hline LNP max (mg/m3) & 1.521 & 0.611 & 0.281 & 0.653 & 0.204 & 0.204 \\
\hline LNP mid (mg/m3) & 0.254 & 0.106 & 0.018 & 0.206 & 0.016 & 0.016 \\
\hline$O_{2}$ (environ) (\%) & 20.8 & 20.8 & 17.05 & 15.2 & 16.89 & 16.89 \\
\hline $\mathrm{CxHy}\left(\mathbf{m g} / \mathbf{m}^{3}\right)$ & & & 4.029 & 10.294 & 6.121 & 6.121 \\
\hline $\mathrm{NO}_{2}\left(\mathrm{mg} / \mathrm{m}^{3}\right)$ & & & $<0.150$ & $<1.50$ & 0.163 & 0.163 \\
\hline $\mathrm{CH}_{4}$ (environ) $(\%)$ & & & $<0.123$ & $<0.23$ & 0.129 & 0.129 \\
\hline CO (environ) (mg/m3) & $<0.01$ & $<0.01$ & 29.3 & 68.8 & 25.8 & 25.8 \\
\hline $\mathrm{SO}_{2}$ (environ) $(\mathrm{mg} / \mathrm{m3})$ & 0.15 & 0.1 & 44.1 & 42.5 & 41.7 & 41.7 \\
\hline $\mathrm{H}_{2} \mathrm{~S}$ (a environ) (mg/m3) & 0.1 & 0.2 & & & & \\
\hline CxHy (Oxhak)(mg/m3) & 16.92 & 36.2 & 20.8 & 20.8 & 20.8 & 20.8 \\
\hline $\mathrm{O}_{2}$ (chimney) $(\mathrm{V} \%)$ & 19.6 & 19.9 & - & - & - & - \\
\hline $\begin{array}{l}\text { TG (Temperatura e gazit te } \\
\text { rrjedhshem) (Oxhaku) }\left({ }^{\circ} \mathrm{C}\right)\end{array}$ & - & - & 0.282 & 0.282 & 0.286 & 0.286 \\
\hline $\mathrm{CO}_{2}$ (chimney) \%) & & & 29.042 & 58.201 & 33.226 & 33.226 \\
\hline CO $\left(\right.$ chimney) $\left(\mathrm{mg} / \mathrm{m}^{3}\right)$ & 11.71 & 45.72 & - & - & - & - \\
\hline $\mathrm{NO}_{2}($ chimney $)\left(\mathrm{mg} / \mathrm{m}^{3}\right)$ & 8.8 & 1.2 & 50.6 & 85.8 & 47.1 & 47.1 \\
\hline $\mathrm{SO}_{2}($ chimney $)\left(\mathrm{mg} / \mathrm{m}^{3}\right)$ & 44.9 & 21.4 & - & - & - & - \\
\hline Solid matter $\left(\mathbf{m g} / \mathbf{m}^{3}\right)$ & 35.6 & 39.8 & - & - & - & - \\
\hline
\end{tabular}


After recycling, depending on the volume, the remaining quantity is either destined for the Sharra landfill or can be used by cement production factories as an additive. All the water used is recycled, purified and cooled in special plant to prevent the problem of waste water disposal.

\section{CONCLUSION}

Aluminum recycling facilities in our country generally work on an environmental protection plan. The flue gas cleaning plant is constantly monitored and subjected to routine maintenance. Emissions from melting furnaces are regularly analyzed to ensure that they comply with applicable regulations. Secondary aluminum production is constantly increasing as it offers economic and environmental advantages.

As a result of the recycling of aluminum scrap we have:

- Economic benefit;

- More sustainable environment;

- And a social welfare.

\section{ACKNOWLEDGEMENT}

The realization of this material was made possible from a good collaboration of Ministry of Environment, National Environmental Agency, Faculty of Natural Sciences, and Albanian Recycle Association.

\section{REFERENCES}

1. Chote, W.U.S. Energy Requirements for Aluminum Production: Historical Perspective, Theoretical Limits, and New Opportunities. In Aluminum Recycling and Processing for Energy Conservation and Sustainability, 1st ed.; Green, J.A.S., Ed.; ASM International: Materials Park, OH, USA, 2007

2. CEN. Aluminum and Aluminum Alloys-Alloyed Ingots for Remelting -Specifications; EN 1676; CEN: Brussels, Belgium, 2010;

3. EUR 22951 EN - Joint Research Centre - Institute for Prospective Technological Studies Title: Prospective Study of the World Aluminium Industry, Luxembourg: Office for Official Publications of the European Communities 2008 EUR - Scientific and Technical Research series - ISSN 1018-5593 ISBN 978-92-79-07357-1

4. ENERGETICS, Columbia, Maryland, July, 1997, Energy and environmental profile of the US aluminum industry.

5. European Aluminium Association (EAA) http://www.aluminium.org/Aluminium recycling the road to high quality products, 2006 Sustainability of the European aluminium industry, 2006

6. Håvard Bergsdal, Anders H. Stromman and Edgar G. Hertwich, 2004. The aluminium industry - environment, technology and production, Norwegian University of Science and Technology (NTNU).

7. International Aluminium Institute (IAI) http://www.world-aluminium.org/Global aluminium recycling a cornerstone of sustainable development, the Global aluminium recycling committee, IAI, 2006 
8. J. Blomberg, S. Hellmer, 2003, Short-run demand and supply elasticities in the West European market for secondary aluminium, Resources Policy 26 (2000) 39 - 50, April, 2003

9. J. Gerber, "Global Aluminum Recycling: A Cornerstone of Sustainable Development," International Aluminum institute, London2009

10. Mark E. Schlesinger, Aluminum recycling, second edition, CRC Press Taylor \& Francis Group

11. Pål Vigeland, 2001, Aluminium recycling: the commercial benefits, the technical issues and the sustainability imperative, Hydro Aluminium Recycling

12. Roadmap from Europe to North America, Workshop on Aluminum Recycling, 2010

13. Velasco, E.; Nino, J. Recycling of aluminium scrap for secondary Al-Si alloys. Waste Manag. Res. 2011,

14. Zolotoresky, V.S.; Belov, N.A.; Glazoff, M.V. Modelling of aluminum scrap melting in a rotary furnace. Miner. Eng. 2006,

15. W. Kukshinrichs and P.N. Martens, Resource- Orientated Analysis of Metallic Raw Materials, series: Matter and Materials, volume 17 (Jülich, Germany: Forschungszentrum Jülich GmbH, 2003

\section{Corresponding author: Eneida Mara,}

Chemical Sub-chapter Coordinator, SANE 27-Support Albanian Negotiation in Environment Chapter 27, Tirana, Albania,

Online date of publication: 30.06 .2021 